\title{
Germinative Power Estimate and Germination Seeds Characteristics of Myrianthus Arboreus (Cecropiaceae) in Semi- Deciduous Forest-Zone of Côte d'Ivoire
}

\author{
AKAFFOU Doffou Sélastique, KOUASSI Kouadio Henri", AGBEKE Mobio Pamphile \\ Université Jean Lorougnon Guédé BP 150 Daloa
}

*Corresponding Author: KOUASSI Kouadio Henri, Université Jean Lorougnon Guédé BP 150 Daloa

\begin{abstract}
Myrianthus arboreus is a food and medicinal wild plant. It can be found in many forest countries in Africa. In order to domesticate this species, a study of characterization and germination of wild seeds was conducted at the University of Jean Lorougnon Guede. Three devices, two seed substrates and three treatments were tested. The results revealed that the device under shade house is the best device for seed germination of M. arboreus with a rate of $92.78 \%$. Red sawdust promotes more seed germination of $M$. arboreus with an average of $87.78 \pm 8.63 \%$. Black soil proved to be the best substrate for the development of seedlings. The rate and germination period does not differ significantly depending on the applied treatments. For germination conservation, the seeds left in the fruit turn out to be the best storage method. M. arboreus can be domesticated from its seeds.
\end{abstract}

Keywords: Myrianthus arboreus, regeneration, seed germination, seed substrate, Côte d'Ivoire

\section{INTRODUCTION}

The edible wild plant species contribute to the food safety of the rural populations. Among these edible plant species, the genus Myrianthus comprises seven species. Three (Myrianthus arboreus, $M$. serratus and M. libericus) of these species are edible [1].

In Côte d'Ivoire, like in many countries of West and East Africa, the young leaves of M. arboreus are consumed as vegetable sauce and sauce Vegetable. The fruits are consumed for their sweetened or acidulated pulp. The young sheets of $M$. arboreus, for [2], present a good content of nutrients (Amino-acid, rough Proteins) and of minerals (Phosphorus, Nitrogenizes, Calcium...)... For famine periods they are one of the main sources of vegetable in the tropical forest zones of Africa. It is also a good source of food for the cattle [2]. M. arboreus played in the past a significant role in the survival of certain populations, especially in crisis period, drought and invasion of cultures by locusts [3].

In addition, $M$. arboreus is used for the treatment of many diseases like dysentery, diabetes, hypertension, etc. for [4]. The extracts of bark are an important source of new pharmaceutical products and natural products for health. The aqueous extracts of $M$. arboreus showed an excellent antibacterial activity compared to chloramphenicol, amoxicillin and in vitro ampicillin [5]. It has the capacity of improving the nitrogen level and soil fertility because of its mycorrhizal associations. Its potash is used for the manufacturing of soap [6]. Its yellowish white wood is difficult to machine but is appropriate for the manufacturing of paper [2]. M. arboreus is sold well on the local and markets. Thus, several companies have a license to export equipment of $M$. arboreus for pharmaceutical issues [2]. This plant is a real source of additional nutritional and financial resources in rural areas. It was formely abundant in the forest and in fallow. This plant with multi-purpose uses is threatened today of extinction by the degradation of the forest heritage. This invaluable plant is still being destroyed for more supposed industrial crops profitability in terms of finance. The situation brings about its rarefaction. Moreover, the seeds of M. arboreus have difficulties to grow under trees because of the strong layer of humus and the shade constituted by its foliage.

The dissemination of this species is ensured by the primates and some small mammals [7]. The varied use and the threats that $M$. arboreus face, are enough to justify the thrust in this research about domestication. But this domestication is not possible without a good command of regeneration techniques and the priority of which is seeds regeneration. 


\section{MATERIAL AND MethodS}

\subsection{Zone of Study}

The works were undertaken within the boundary of Jean Lorougnon Guédé University located in Daloa at Mid-west of Côte d'Ivoire (6 $6^{\circ} 54^{\prime} 28^{\prime}$ ' $\mathrm{N} ; 06^{\circ} 26^{\prime} 25^{\prime \prime} \mathrm{W}$, Fig. 1). The subequatorial climate is characterized by two types of seasons: two rainy seasons (March to June and September to October), which alternate with two dry seasons of which largest is located during the time going from November to February.

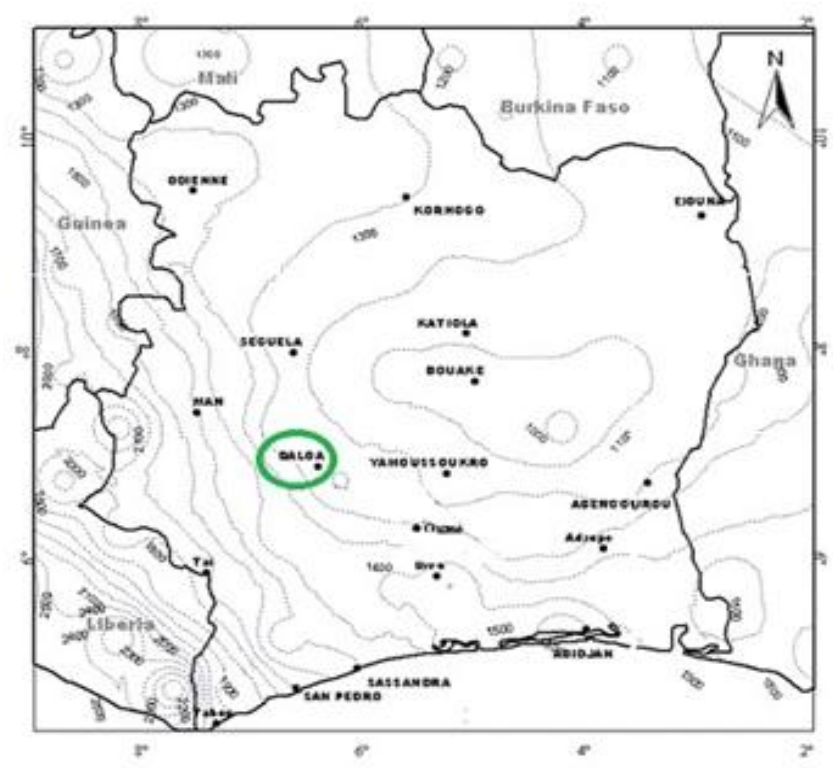

Zone of study

Fig1. Location of the study zone

\subsection{Material}

\subsubsection{Biological Material}

Biological material is composed of seeds of M. arboreus (Fig. 2) and of two types of substrates of sowing (Fig. 3; Black soil and red Sawdust). The work is about sample of 1290 seeds extracted from ripe fruits of $M$. arboreus. These fruits are from only one genotype located in the forest park of Marahoué (6 $\left.6^{\circ} 54^{\prime} \mathrm{NR} ; 6^{\circ} 09^{\prime} \mathrm{W}\right)$ to $1700 \mathrm{~m}$ of Djahakro (Gonaté) on Yamoussoukro-Daloa axis.

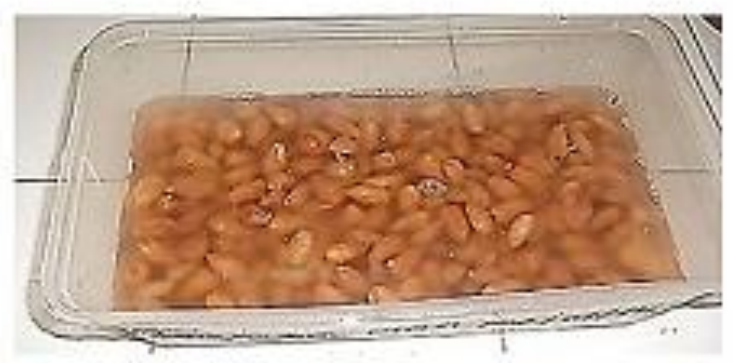

Fig2. Seeds extracted from ripe fruits

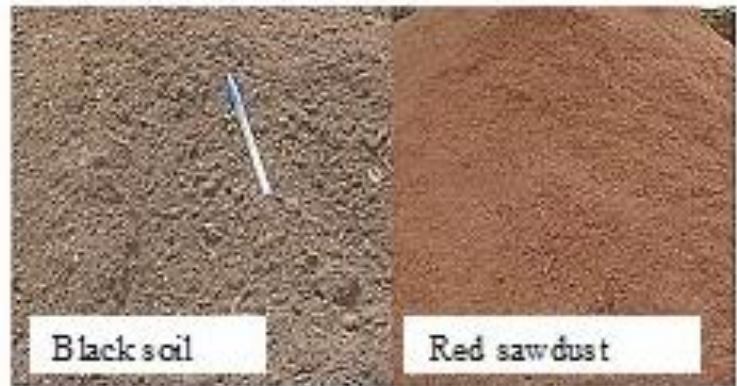

Fig3. Seeding substrates

\subsubsection{Technical material}

The technical material used in this study is composed of a camera to take photos, a GPS (Globaling positionning system) for geographical data, a slide caliper for measurement and a thermo-hygrometer for temperature and relative humidity in the various devices, some long polyethylene sachets of $6 \mathrm{~m}$ for greenhouse construction. 


\subsection{Methods}

\subsubsection{Germination rate of M. arboreus seeds}

\subsubsection{Devices for study}

Three devices for experimentation (Fig. 4) were set up for the study of the germination seeds rate of M. arboreus:

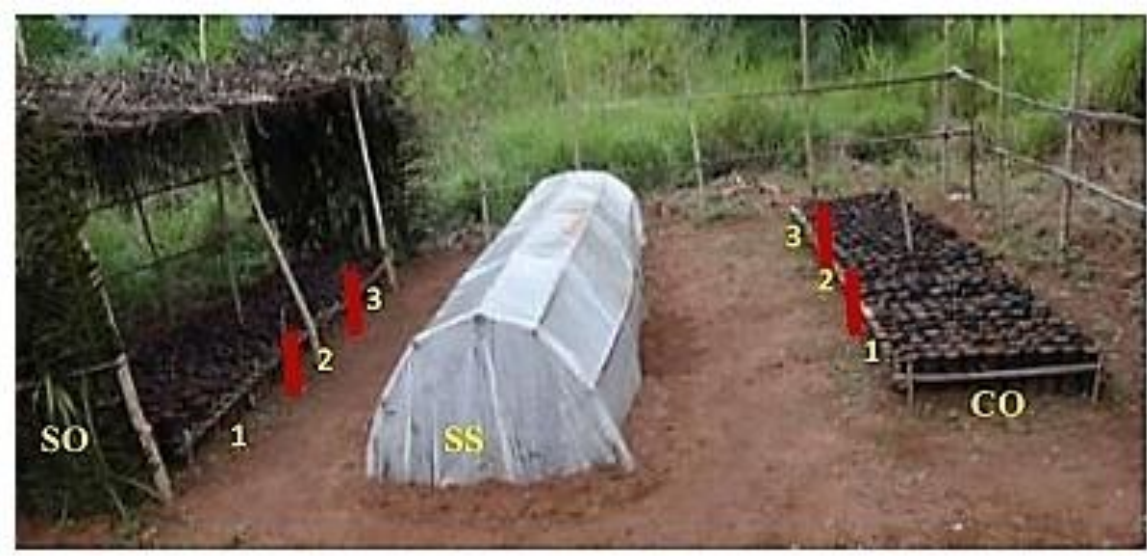

Fig4. Expérimental devices: SO (under shading), SS (under greenhouse), CO (Exposed in under).

- a device exposed in the sun (CO),

- a device under greenhouse (SS),

- a device under shading (SO).

Each device contains 360 polyethylene sachets laid out in three blocks of 120 units. The sachets contain two types of substrate: black cotton soil (TN) and red sawdust (SC).

Sachets sowing and treatment

The ripe fruits of medical $M$. arboreus in good state were harvested into bag and were taken to the site of the seedbed. The seeds of these ripe fruits were manually extracted, washed twice with tap water then sorted according to their density compared to water. All floating seeds were eliminated. The heaviest were retained for germination test. They were left again in three batches of 360 seeds. The first batch was used as witness (WP). The second batch was soaked into water (GTE) with $35^{\circ} \mathrm{C}$ for 24 hours with water change after twelve (12) hours of steeping. The third batch was soaked into hydrochloric acid (AWG, 1\%) for 4 hours. The seeds were then sown vertically in the substrates for 2 $\mathrm{cm}$ depth. Each type of substrate received 20 seeds of each type of treatment per block. The distribution of seeds within each block is presented in Table 1. Each sachet carries a label which indicates the treatment undergone by seed that it contains (green: WP; blue: GTE and red: AWG).

Table1. Distribution of seeds in the substrates within the blocks in each device

\begin{tabular}{|c|c|c|c|}
\hline Block & Sbstrats & Treatments & Number of seeds \\
\hline \multirow{3}{*}{ Block 1 } & Witness & 20 \\
\cline { 2 - 3 } & \multirow{3}{*}{ Black soil } & GTE & 20 \\
\cline { 2 - 3 } & & GTA & 20 \\
\cline { 2 - 3 } & Red sawdust & Witness & 20 \\
\cline { 3 - 4 } & & GTE & 20 \\
\cline { 3 - 4 } & & GTA & X 20=120 \\
\hline
\end{tabular}

\subsubsection{The germinability of Myrianthus arboreus}

Installation of the study device

A fourth device exposed in the open was set up for the study for the duration of germinative power and for the mode of seeds preservation. This device was left again in four blocks (a block of 30 units and three blocks of 60 units each; Fig. 6) containing 210 sachets of black soil. 
Treatment and sowing of the sachets

Two batches of seeds were made up for the study for the duration for the germinative power and the mode of seeds preservation. First is composed of 120 seeds. These seeds were treated as described above, and then spread out in the laboratory on paperboard, at a temperature ranging between 18 and $28{ }^{\circ} \mathrm{C}$. The second batch was composed of a mature fruit containing seeds protected from the sun. Then, seed samples were regularly taken from batches of seeds spread out in the laboratory and in mature fruit. Thirty (30) of a hundred and twenty 120 extracted seeds were sown the same day (1st). The remaining seed was sown gradually after 7 days of preservation in the laboratory and 27 days of preservation in the mature fruit. With each seed, thirty (30) seeds of each batch were sown. Each sachet carried a label which indicated the type of seed that it contained (Green: seed contained in the fruit, Red: seed preserved in the laboratory).

\section{Culture}

The devices under shading and the device exposed under the sun were watered every day. The device under greenhouse was watered every five days to limit the exchanges with external environment. The seedbed was regularly weeded to avoid all competitions. Temperature and relative humidity were recorded each day to follow their variation within each device. Then, after germination, each germinated seed was put in the earth. The counting of germinated seeds was carried out by five days interval for 60 days. This counting made it possible to evaluate the rate, the time, as well as the seeds germination duration of $M$. arboreus. The rate of germination (TG) was estimated by the following formula:

TG $(\%)=,=\frac{n}{N} * 100$ with $\mathrm{N}=$ number of germinated seeds and $\mathrm{NR}=$ Number of sown seeds. The average time (DM) $\frac{\sum n i t i}{n}$ of germination is the period from sowing to the removal of sowings.

$\mathrm{DM}$ (days) $=$, with $\mathrm{Ti}=$ period of germination for every seed; seed $\mathrm{ni}=$ effective germinated seeds for the same period; $\mathrm{N}=$ Number of germinated seeds.

Characterization of growth and young plants development.

The development and the growth of the seedlings were evaluated. For this purpose, the diameter of the neck (cd), the height of the plant (HP), the length and the width of the sheets as well as the number of sheets per stem, were recorded. These measurements made it possible to evaluate the development and the growth of every part of the seedlings twenty-five (25) days after the removal of sowings on every substrate.

\subsection{Data Analysis}

A variance analysis was used to highlight the differences between the averages of the seeds germination. These analyses were carried out, using a software (STATISTICA 7.1). This analysis consisted in testing the effect of three factors (Device, Substrate and Treatment) individually as well, in interaction, from the germination seeds rate and young plants development.

\section{RESUltS}

\subsection{Germination of the Seeds of Myrianthus Arboreus}

The germination of the seeds of $M$. arboreus was twenty five days after their sowing within the devices under shading within the device exposed in the open air whatever the treatment and the type of substrate. The seeds continued to germinate for fifty days under shade and sixty (60) days within the device exposed under the sun. The number of germinated seeds was very high under shading (334) and within the device exposed in sun (271). However, after twenty-five (25) days, no seed had germinated under greenhouse.

\subsubsection{Devices influence on germination rate}

Germination rates (Fig. 5) differ significantly from the devices $(\mathrm{P}=0.0000)$. The rates are about $92.78 \%$ for the device under shading, $75.28 \%$ for the device exposed under the sun and $00.00 \%$ for the device under greenhouse 
Germinative Power Estimate and Germination Seeds Characteristics of Myrianthus Arboreus (Cecropiaceae) in Semi-Deciduous Forest-Zone of Côte d'Ivoire

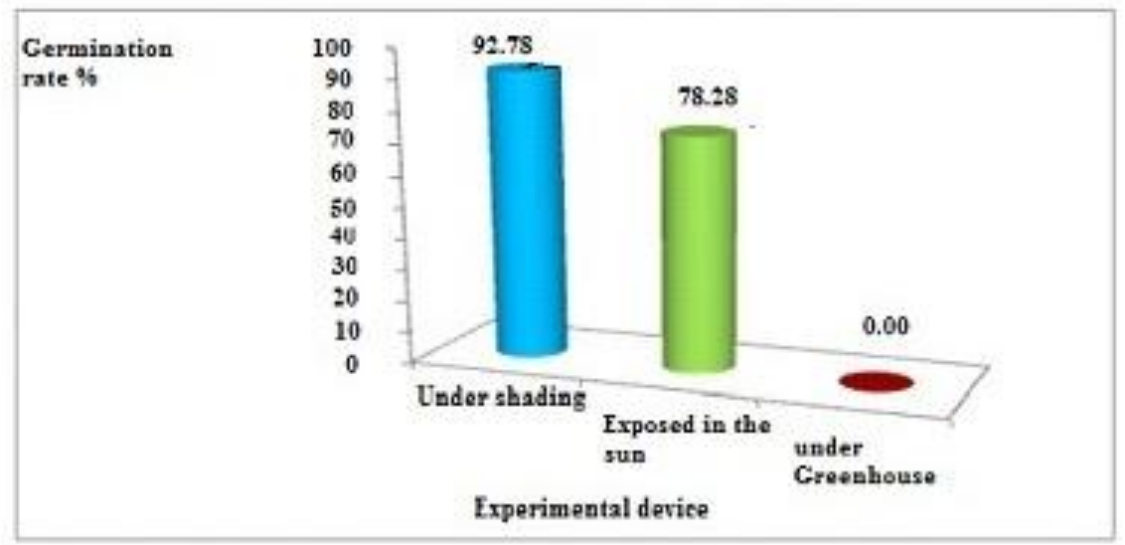

Fig5. Germination rate estimation from divices

\subsubsection{The substrates influence on the germination rate}

It was recorded on the red sawdust $87.78 \pm 8.63 \%$ of germination against $80.28 \pm 15.40 \%$ of germination on the black soil. The variance analyses of average rates of germination showed that these average rates differ significantly from a substrate to another $(P=0.0038)$. This difference is also observed with the device exposed in the sun (Table 2).

Table2. Sbstrates influence on seeds germination rate

\begin{tabular}{|c|c|c|c|}
\hline & \multicolumn{3}{|c|}{ Devices } \\
\hline Sbstrates & Under shading & Exposed in sun & Average \\
\hline Black soil & $91.67 \%$ & $68.89 \%$ & $80.28 \pm 15.40 \%$ \\
\hline Red sawdust & $93.7 \%$ & $81.67 \%$ & $87.78 \pm 8.63 \%$ \\
\hline
\end{tabular}

\subsubsection{Treatments influence applied to germination rate}

No significant difference was observed between germinations rates of treated seeds and those of untreated seeds $(\mathrm{P}=0.054$; Table 3$)$.

Table3. Treatments influence on seeds germination

\begin{tabular}{|c|c|c|c|}
\hline & \multicolumn{3}{|c|}{ Devices } \\
\hline Treatments & Under shading & Exposed in sun & Average \\
\hline Seeds soaked into acid & $95.00 \%$ & $80.83 \%$ & $87.92 \pm 10.0 \%$ \\
\hline Seeds soaked into water & $91.67 \%$ & $74.66 \%$ & $82.92 \pm 12.4 \%$ \\
\hline Witness seeds & $91.67 \%$ & $70.83 \%$ & $81.25 \pm 14.7 \%$ \\
\hline
\end{tabular}

The number which carry the same letter are not different and the number carrying different letter are different

The average germination rate recorded from the treatments is of: $87.92 \pm 10 \%$ for seeds soaked into acid, of $82.92 \pm 12.4 \%$ for seeds soaked into water and of $81.25 \pm 14.7 \%$ for witness seeds.

\subsubsection{Treatments influence on germination period}

The average germination period of treated seeds do not differ from that of untreated seeds (Table 4). Indeed, the average periods vary from $33.04 \pm 5.76$ days to $35.43 \pm 5.24$ days. The variance analysis did not reveal a significant difference. In the same token, no significant difference in germination period was recorded within the experimental devices.

Table4. Treatments influence on average seeds germination period

\begin{tabular}{|c|c|c|c|}
\hline & \multicolumn{3}{|c|}{ Devices } \\
\hline Treatments & Under shading & Exposed in sun & Average \\
\hline Witness seeds & $34.63 \pm 4,52^{Z}$ & $36.23 \pm 5,97^{Z}$ & $33.43 \pm 5.24^{Z}$ \\
\hline $\begin{array}{c}\text { Seeds soaked into water } \\
35^{\circ} \mathrm{C}\end{array}$ & $32.44 \pm 4.60^{Z}$ & $34.83 \pm 6,50^{Z}$ & $3.28^{Z}$ \\
\hline $\begin{array}{c}\text { Seeds soaked into acid } \\
1 \%\end{array}$ & $32.94 \pm 4.75^{Z}$ & $33.14 \pm 6,77^{Z}$ & $33.04 \pm 5.76^{Z}$ \\
\hline Average & $33.33 \pm 47.44^{Z}$ & $34.73 \pm 6.41^{Z}$ & \\
\hline
\end{tabular}

The number which carry the same letter are not different and the number carrying different letter are different 


\subsection{Period of M. Arboreus Seeds Germination Capacity}

The rate of seeds germination contained in fruit decreases gradually with the shelf life (Fig. 6). This rate decreases from $36.6 \%$ to $26.6 \%$ and at $20 \%$ after $7 ; 17$ and 27 days of preservation in the fruit, respectively. In addition, the seeds extracted from the fruits and kept in the laboratory at a temperature ranging from 18 to $28^{\circ} \mathrm{C}$, have a germination rate of $33.33 \%$ after seven days of preservation; which rate is cancelled after 17 days of preservations.

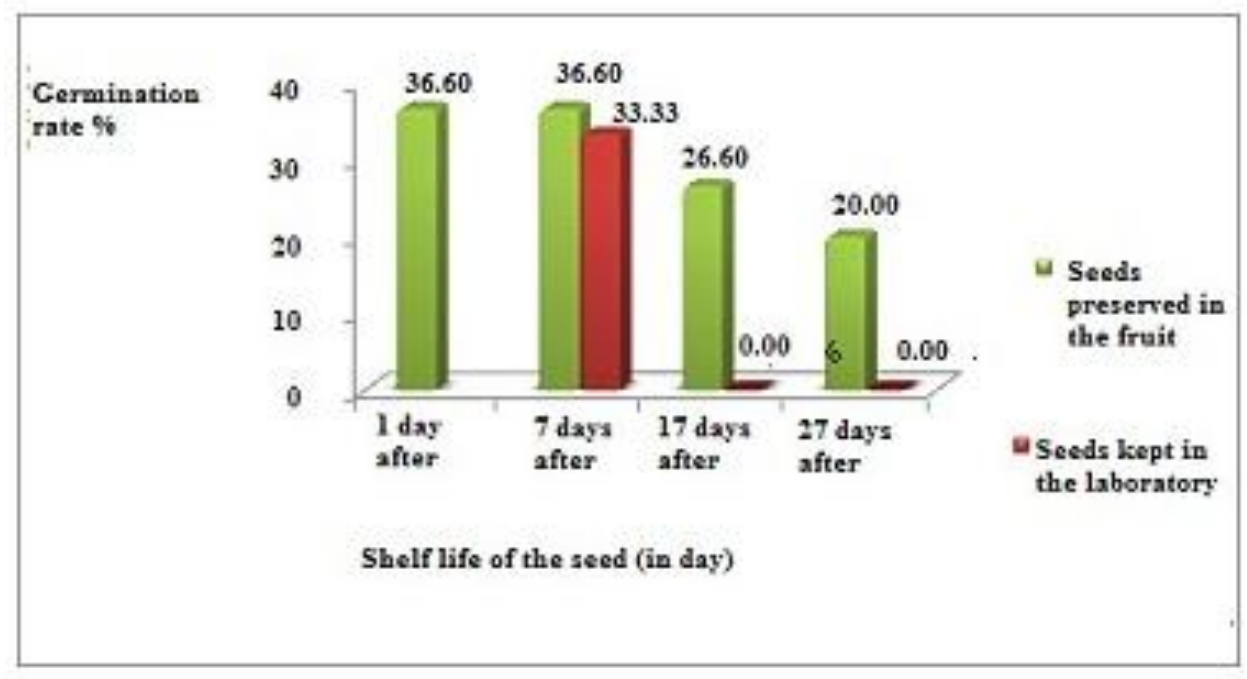

Fig6. Estimate germination rate period and Myrianthus arboreus seeds mode of preservation

\subsubsection{Growth and size development of young plants of M. arboreus}

The appearance of the two first leaves of the cotyledons begins two days after the removal of seeds on the two substrates of sowing. After ten days of growth, the first bodies reach their maximum length and the 11th days the second inter-node appears with new leaves. The digitations of the leaves began starting from $79 \pm 5$ days that is to say with the appearance of the eighth or the ninth knots. The influence of the substrate on the growth of the young plants is perceptible starting from the 25th days (Table.5). Indeed, a significant difference was observed on the length level, the width and the number of leaves between the young plants visible on the two substrates. However, the variations on the level of the size of these young plants are not perceptible from one substrate to another.

Table5. Height growth of the seedings in the various types of substrates

\begin{tabular}{|c|c|c|c|c|c|}
\hline Substrates & $\begin{array}{c}\text { Diameter of } \\
\text { the neck }\end{array}$ & $\begin{array}{c}\text { Height of } \\
\text { the stem }\end{array}$ & $\begin{array}{c}\text { Leaves } \\
\text { length }\end{array}$ & $\begin{array}{c}\text { Leaves } \\
\text { width }\end{array}$ & $\begin{array}{c}\text { Number of } \\
\text { leaves }\end{array}$ \\
\hline Black soil & $0.194 \pm 0.03^{a}$ & $6.17 \pm 1,32^{z}$ & $5.88 \pm 0,99^{z}$ & $4.74 \pm 0,76^{z}$ & $4.18 \pm 0.95^{a}$ \\
\hline Sawdust & $0.183 \pm 0,03^{b}$ & $5.83 \pm 1,28^{z}$ & $5.51 \pm 0,92^{b}$ & $3.88 \pm 1,42^{b}$ & $3.73 \pm 0.73^{b}$ \\
\hline
\end{tabular}

\section{DISCUSSION}

\subsection{Arboreus Seed Germination}

The device under shading brought us to record the best rate of germination and the best growth of the seedlings for the period of this study. The ecological conditions provided by every device are probably the factor which discriminates the germination rates within every device. Indeed, the temperatures which vary from $+22.5^{\circ} \mathrm{C}$ to $37^{\circ} \mathrm{C}$, with an average of $29.53 \pm 1.99^{\circ} \mathrm{C}$ give room to a good rate of germination for the device under shading, while the temperatures of $24^{\circ} \mathrm{C}$ and $54.5^{\circ} \mathrm{C}$ with an average of $39.19 \pm 4.54^{\circ} \mathrm{C}$ cause seeds rotting under greenhouse. $M$. arboreus would have an optimal temperature of germination in seed nurseries beyond which this one would be impossible. This temperature would be between $22.5^{\circ} \mathrm{C}$ and $37^{\circ} \mathrm{C}$. These results are similar to those of [8] with seeds of Argan. For these seeds, the ideal temperature of germination is about $28^{\circ} \mathrm{C}$. According to [9] with seeds of sessile oak, when the temperature of germination is high, the development of the various components is fast. The temperature period tested is 13 to $20^{\circ} \mathrm{C}$. In the substrates, the greatest rate of germination was recorded in the red sawdust. Germination was much more homogeneous in that substrate than in the black soil. This difference could be due to the modification of the physical 
properties of the black soil in the sachets following the alternation of strong rains and strong heats within the device exposed in sun. Indeed, black soil with a good structure allowed it to better preserve moisture. When the soil becomes compacts, it ensures a bad ventilation of seeds. Indeed, the quantity and the quality of oxygen in the substrate play a determining role in the process leading to the germination of the plant. The sawdust with a more or less coarse structure is withered quickly on surfaces because of its greatest permeability and infiltration is more or less fast deep within the watering water. However, it ensures a better ventilation of seeds; what would facilitate germination. On the other hand the seedlings become yellow on this substrate after thirty-two days of growth, whereas those germinated on the black soil grow normally. These results are in line with those of [10] who worked on Gambeya lacourtiana seeds. They showed that a mixture of black soil with the sawdust with $2 / 3$ and $1 / 3$ proportions reveals the best germination possibilities and growth of the seedlings.

The rate and germination period do not differ significantly according to the standard treatments from substrate. However, the long times (more than 30 days) can be related to the dormancy of certain seeds. The absence of variation on the level of germination period could be related to the quality of the treatment of seed before sowing. However, seeds germination periods recorded for this work were shorter than those recorded by [7], with seeds of M. arboreus. These works shown that the witness seeds extracted the ripe fruits germinated at the end of 75 days whereas the seeds taken in the large intestine of the primate (Cercopithecus nictitans) and sown, germinated within 60 days. The period of germination could be reduced to a treatment more stressing for the seed (an increase in water temperature or acid concentration). The works undertaken by [11] on seeds of Prosopis africana shown that the scalding of the seeds for three (3) minutes then steeping in tap water for 24 hours and the soaking of the seeds into the concentrated sulphuric acid for fifteen minutes considerably reduced the period of seed germination .

Germination rates of witness seeds obtained (70.83\% with device exposed under the sun and $91.67 \%$ under shading) differ from the results of [12] and from those of [13]. For [12] M. arboreus seeds germination rate is $40 \%$, whereas [13] recorded a germination rate of $60 \%$. These results that highlight the good germination and reproduction capacity of $M$. arboreus under supervised environment that is domestication.

\subsection{Germinability Power of M. Arboreus Seeds}

The various experiments indicated that the seeds of $M$. arboreus extracted from the ripe fruits lose their germinative power beyond seventeen days of drying for temperatures ranging from eighteen to twenty eight $\left(28^{\circ} \mathrm{C}\right)$. The seeds germinability is optimal in the fruits and gradually decreases with the shelf life. This would be due to water content of seeds following drying. The behavior of seeds after their extraction of the fruits showed that they last are sensitive to drying. This fall would be related to the water loss of seeds during drying. Thus, the strong fall of the quantity of water in seeds causes the loss of the germinability. This level of dehydration that the seeds of $M$. arboreus would not support stand at the end of seventee days of drying in the laboratory. The seeds of M. arboreus would have a similar behavior with those of Carapa procera. Acording to [14] a reduction of water content for those seeds for a relatively weak level $(<20 \%)$ would cause the lost of germination power. Simlarly [14] showed that the seeds of Garcinia kola lost their germination power when their water content is lower than $30 \%$.

\subsection{Development and Growth of the Young Seedlings of M. Arboreus}

The measures taken for the seedlings aged twenty five (25) showed that the development of this one varied from a substrate to another. The analysis of these measurements emphasized a better development of the seedlings of $M$ arboreus on the black soil compared to the red sawdust. These results would confirm the work of [10] with Gambeya lacourtiana. Indeed, this work highlights a better growth of the species like Gambeya lacourtiana and Lovoa trichilioides on a substrate made up of a mixture of sand (30\%) and black soil (70\%). Similary [15] and [16]. Posited that the suitable substrate in seedbed is a mixed composition of sand and humus-bearing soil in $1 / 3$ and $2 / 3$ proportion, respectively biogenic salts in these various substrates. On the black soil, the seedlings resulting from whiteness seeds are as vigorous as the seedlings resulting from seeds soaked in water and acid. The assumptions that could explain those results are the chemical composition and the availability of 
minerals within those different (various) substrates. On the black soil, the seedlings from witness seeds are as strong as seedlings soaked into water and acid. These results are opposed to those of [7]. The researchers have highlighted that the seedlings from ingested seeds by Cercopithecus nictitants were stronger than those resulting from the witness. On the red sawdust the seedlings leaves become yellow thirty-two (32) days after seeds germination. The exhaustion of assimilable minerals in the red sawdust could be at the basis of this yellowing. Indeed, for [17], in seed nurseries, the substrate must be made up of easily degradable organic matters to give good performances.

\section{CONCLUSION}

The thrust of this study was to test the regeneration of $M$. arboreus by seeds. Three devices, two types of farming substrates and three pretreatments were tested. These investigations showed that the device under shading is the best for the germination of the seeds of $M$. arboreus. The sawdust is the suitable substrate for the germination of seeds. However, the black soil proves to be the best substrate for the development of the seedlings. The rate and the period of germination do not differ significantly from the treatments applied. It comes out from all that precedes that $M$. arboreus can be domesticated easily. For the germination of its seeds, the device under shading and the substrates rich in nutritive elements (black soil) are best indicated. In addition, the seeds left in the fruit better preserve germination power.

\section{REFERENCE}

[1] Kouamé N.M.T., Gnahoua G.M., Konan E. Kouassi K.E.et Traoré. D. Les plantes spontanées alimentaires de la Région du Fromager (Gagnoa): Flore, habitats et organes consommés. Sciences \& Nature, 2008. 5 (1): 61-70.

[2] Amata IA. Valeur nutritive des feuilles de Myrianthus arboreus: UN parcours des végétaux. International Journal of Agricultural Research; 2010; (5): 576-581.

[3] Gautier-Beguin D. Etude ethnobotanique des plantes de cueillette à utilisation alimentaire dans un village au sud du V-Baoulé (Côte d'Ivoire). Thèse de Doctorat. Université de Genève; 368 p (1992).

[4] Apema .R. Mozouloua.D. Abeye.J. Salamate. F.M.F. Les plantes médicinales utilisées dans le traitement du diabète par les tradipraticiens à Bangui; 2011.

[5] Agwa O.K., Chuku W. and Obichi E.A. The in vitro effect of Myrianthus arboreus leaf extract on some pathogenic bacteria of clinical origin. Journal of Microbiology and Biotechnology Research, 2011. 1 (4):77-85

[6] Orwa C., Mutua A., Kindt R., Jamnadass R., Simons A. Agroforesterie base de données: un guide de référence et la sélection arbre version 4.0; 2009. (http//www. Worldagrofo restry.org/af/treedb) 5

[7] C. M. Hladik, A. Hladik. Observations sur le rôle des Primates dans la dissémination des végétaux de la forêt Gabonaise. BiologiaGabonica; 1967; (3):.43-58.

[8] S. Berka et A. Harfouche. Effets de quelques traitements physico-chimiques et de la température sur la faculté germinative de la graine d'Arganier. Revue forestière française; .2001; 53 (2): 125-130.

[9] M. Guibert et C. Le Pichon. Influence de la température sur la germination, la levée et sur les taux de semis à tiges multiples chez le chêne sessile. Revue forestière française ; 2001 ; 53 (1) : 44-54.

[10] Nguema N. P., Ondo-Azi A. S., Mouele B. J., Ntsame. Effet de la composition de différents substrats culturaux sur quelques paramètres de croissance de Gambeya lacourtiana De Wild en pépinière au nord-est du Gabon Journal of Applied Biosciences ; 2014 ; (73):5902-5910

[11] L.E. Ahoton, J.B. Adjakpa, M'po I. M., E.L. Akpo. Effet des prétraitements des semences sur la germination de Prosopis africana (Guill., Perrot. et Rich.) Taub., (Césalpiniacées) TROPICULTURA ; 200927 (4) : 233-238

[12] Okafor, J.C Myrianthus arboreus P.Beauv, Grubben, G.J.H. \& Denton, O.A. PROTA (Ressources végétales de l'Afrique tropicale; 2004.

[13] Djaha A. J. B., Gnahoua G. M. Contribution à l'inventaire et à la domestication des espèces alimentaires sauvages de Côte d'Ivoire: Cas des Départements d'Agboville et d'Oumé. Journal of Applied Biosciences ; 2014 ; (78): 6620-6629

[14] Agyili J., Sacande M., Koffi E., \&Peprah T. Improving the collection and germination of West African Garcinia kola Heckel seeds. New Forests; 2007; (34): 269-279.

[15] Weigel, J. Agroforesterie pratique à l'usage des agents de terrain en Afrique tropicale sèche. Paris, Ministère de la Coopération; 211 p (1994). 
Germinative Power Estimate and Germination Seeds Characteristics of Myrianthus Arboreus (Cecropiaceae) in Semi-Deciduous Forest-Zone of Côte d'Ivoire

[16] Ammari Y., Lamhamedi M. S., Akrimi N., ZineElAbidine A. Compostage de la biomasse forestière et son utilisation comme substrat de croissance pour la production de plants en pépinières forestières modernes. Revue de 1'I.N.A.T., Tunisie ; 2003; 18: 99-119

[17] Schippers C. Valorisation des pépinières villageoises, Rapport de mission, Projet DACEFI, Nature + Gembloux ; 47 p (2007).

Citation: AKAFFOU Doffou Sélastique et al." Germinative Power Estimate and Germination Seeds Characteristics of Myrianthus Arboreus (Cecropiaceae) in Semi-Deciduous Forest-Zone of Côte d'Ivoire" International Journal Of Research Studies In Biosciences (Ijrsb), Vol. 7, no. 3, pp. 27-35, 2019. http://Dx.Doi.org/10.20431/2349-0365.0703004

Copyright: (C) 2019 Authors. This is an open-access article distributed under the terms of the Creative Commons Attribution License, which permits unrestricted use, distribution, and reproduction in any medium, provided the original author and source are credited. 